\title{
The history of Luiz Simões Lopes: a leader between administration and politics
}

\section{Daniel Ouriques Caminha'}

1 Universidade do Estado de Santa Catarina / Centro de Ciências da Administração e Socioeconômicas, Programa de Pós-Graduação em Administração, Florianópolis / SC — Brazil

\begin{abstract}
This study is based on a biographical methodology and aims to analyze the social origin, history, ascension strategies, and inherited or acquired social resources of Luiz Simões Lopes. The research observes the respective principles of legitimation of Luiz Simões Lopes, a man trusted by Getúlio Vargas in the direction of the Administrative Department of Public Service (Dasp) during the Brazilian period called Estado Novo (New State). Given the hypothesis of a peripheral condition of Brazilian society and, consequently, the absence of social structures in which the professional title is the main criterion of social hierarchy, this article explains the conditions that led Simões Lopes to be part of a ruling elite that imported models and principles from the North American scientific administration. The conclusion is that, due to the existing roots of personal domination in Brazil, the new rationalformal resources were established in the political struggles for Brazilian state control.
\end{abstract}

Keywords: Luiz Simões Lopes; ruling classes; Vargas Era.

\section{Luiz Simões Lopes entre administração e política: a trajetória de um dirigente}

A partir da utilização do método biográfico, este estudo teve por objetivo analisar a origem social, a trajetória, as estratégias de ascensão, os recursos sociais herdados ou adquiridos e os respectivos princípios de legitimação de Luiz Simões Lopes, um dos homens de confiança de Getúlio Vargas incumbido de dirigir o Departamento Administrativo do Serviço Público (Dasp) durante o período do Estado Novo. Seguindo a hipótese que afirma acerca da condição periférica da sociedade brasileira e, consequentemente, da inexistência de estruturas sociais em que o título profissional seja o principal critério de hierarquização de uma sociedade humana, propôs-se aqui explicitar e analisar os condicionantes sociais que levaram Luiz Simões Lopes à condição e ao reconhecimento enquanto elite dirigente responsável pela importação de modelos e princípios da administração científica norteamericana. Assim concluiu-se que, em função das bases de dominação pessoal já existentes, os novos recursos racional-formais importados foram redefinidos nas lutas políticas pelo controle do Estado brasileiro.

Palavras-chave: Luiz Simões Lopes; elites dirigentes; Era Vargas.

\section{Luiz Simões Lopes, entre administración y política: la trayectoria de un dirigente}

A partir del método biográfico, este estudio tiene como objetivo analizar el origen social, la trayectoria, las estrategias de ascenso, los recursos sociales heredados o adquiridos y los respectivos principios de legitimación de Luiz Simões Lopes, uno de los hombres de confianza de Getúlio Vargas en la dirección del Departamento Administrativo del Servicio Público (DASP) durante el Estado Nuevo. Por la hipótesis sobre la condición periférica de la sociedad brasileña y, consecuentemente, la inexistencia de estructuras sociales en que el título profesional sea el principal criterio de jerarquización de una sociedad humana, este estudio se propone explicitar y analizar los condicionantes que llevaron a Luiz Simões Lopes a la condición de elite dirigente responsable de la importación de modelos y principios de la administración científica estadounidense. Se concluyó que, en función de las bases de dominación personal ya existentes, los nuevos recursos racionales-formales importados se redefinieron en las luchas políticas por el control del Estado brasileño.

Palabras clave: Luiz Simões Lopes; elites dirigentes; Era Vargas. 


\section{INTRODUCTION}

Based on a biographical study of the Trajectory of Luiz Simões Lopes, leader of the administrative reform of the state during Vargas's first administration, this study intends to present new contributions to the understanding of transformations that took place in the leading elites of the Brazilian republic from 1930 to 1945 on a national and civil level. It is pertinent to strengthening the theoretical field related to the study of societal elites in the world periphery, like Brazil, and also contributes to discussions about the transformations of these elites examined through the prism of French historic sociology.

Given this, support will be sought for two arguments that will be formulated here based on research that has already been conducted on this subject: a) even with the structure and professionalization of the state, which was the development of a growing social hierarchization based on cultural capital, the legitimate criterion of the hierarchization of the nation's leading elite during this period was an amalgam of a recognition of personal charisma and the impersonal logic of formal-bureaucratic rationality (Coradini, 1997a, 1997b, 2003; Miceli, 2001a; Seidl, 2008, 2010); b) the importing and manipulation of scientific administration from American learning and governmental institutions, but during this period this did not serve to structure an academic field of administration in Brazil, but rather this capital was converted and used in power struggles (Bourdieu, 1996) and as knowledge related to its form and direction (Dezalay \& Garth, 2002), and as a result, it was used to oppose the "old politics" of the traditional oligarchical elites and give the new leading "cosmopolitan" elites a broader social role, giving them a missionary and heroic feeling, authorizing and legitimating their construction of the state (Pécaut, 1990).

Thus, empirical indications will be presented to examine the career of Luiz Simões Lopes from his birth in 1903 until the end of the regime of the New State. Thus, the objective will be to examine his family origins, his social and professional trajectory, his inherited and acquired resources and their respective principles of legitimacy which supported his entry into leadership positions in the highest levels of the state, specifically the fact that he ascended to the leadership of one of the most influential government bodies created under the tutelage of the New State, the Administrative Department of Public Service (DASP), and through political support from Getúlio Vargas and his allies, led the administrative reform of the state playing the role of one of the main facilitators of the import and application of scientific administration within the government.

Simões Lopes was selected not just due to his great notoriety due to his leadership of the modernization of the public civil service, an achievement which was certainly important to Brazilian public administration, but also because he represented a typical figure whose trajectory often made him incorporate contradictory dispositions: a unique amalgam of personal charisma and a very rational nature. This makes it possible to demonstrate with great historical-documental clarity the juxtaposition of the legitimization's logic and principles that were different from those which were prevalent at the time (Bourdieu, 2008), a trait that was very characteristic of the elites of that new era in our national history.

To achieve this purpose, this article is divided into five sections, including the introduction. The second section addresses the systemization of its theoretical-analytical resources. The third will present this study's methodology, while the fourth will describe the analysis of the social factors that 
conditioned the trajectory of Luiz Simões Lopes. The last section will offer this study's conclusions and a systemized presentation of its findings.

\section{ANALYTICAL-THEORETICAL RESOURCES}

The 1930s are considered a watershed in terms of the introduction of institutional recruitment mechanisms in the Brazilian state. This theorization originated mainly from political agents who occupied privileged positions in the state at the time. Even though these acts have been verbalized by these men, social science researchers (Diniz, 1999; Graham, 1968; Nunes, 2003; Siegel, 1964) since then have pointed to the historical persistence of a certain amalgam that mixes personal and impersonal logic in this sphere.

Despite these contributions, which have been more directed towards institutional analyses than the empirical demonstration of transformations in the elites that directed these institutions during times of institutional change, few studies have sought to analyze the conditions that could have determined these transformations and their respective reconfigurations of the principles of legitimization of the leading elites which were behind these processes (Bordignon, 2013; Codato \& Franz, 2018; Coradini, 1997a, 1997b, 1998, 2003; Dezalay \& Garth, 2002; Garcia, 1993a, 1993b; Grill, 2015; Grynszpan, 1990; Loureiro, 1997; Martins, 1987; Miceli, 1981, 2001a; Pécaut, 1990; Petrarca, 2017; Saint-Martin, 1988; Seidl, 2008, 2010). In the search for a reference which will make it possible to analyze what is being proposed, the reference with the greatest sociological and historical character has been selected, even though it is used as a resource above all in the analysis of trajectories rather than the analysis of institutions. It originated in France during the 1970s based on the work of the sociologist Pierre Bourdieu $(1982,2004,2011)$. This angle has proved heuristically useful in revealing the determinant resources and strategies in the formation and recomposition of leading groups within certain contexts.

Considering the specificities of French society, where there is greater alignment between professional positions and social positions, some procedures have been used to make this study of elites in peripheral societies more flexible (Coradini, 2008; Seidl \& Grill, 2013). As Coradini (2008) points out, its use in the Brazilian case presents a series of conceptual and methodological problems. The principal one of these is that the inexistence of a social structure that ensures an equivalence between a professional title and a social position, "implies that the strategies of the agents, as a consequence, are related to the accumulation of personified symbolic capital, as a condition to ensure other forms of capital" (Coradini, 1997a, p. 426). However, personified symbolic capital is understood to be a form of recognition based on fame itself. This type of valuing of capital assumes, according to Sapiro (2012), recognition through singular charisma rather than institutional ties and titles. Therefore, the legitimizing of oneself with charismatic authority in the eyes of the public remains associated with a person. To be effective, it requires a network of personal relationships that is maintained and the notoriety from this is derived from accomplishments that are based on personalized codes of honor and heroism.

In societies in which these spheres have not achieved the same autonomy as in France, the social value of titles obtained within them cannot be disassociated from the position occupied by the agent based on other social resources. When non-institutionalized and non-objective mechanisms prevail, the approach of objective capital in "fields" is given less analytical weight and the approach of personal 
relationships is given greater weight, considering that in this case this type of relationship is structural and not residual. In these terms, the concept of social capital developed by Bourdieu (1998, p. 67) in which "the set of current and potential resources is related to the possession of a durable relationship network that is more or less institutionalized through inter-knowledge and inter-recognition," has yielded more results than demonstrated in France, considering that there the legitimate criterion for the recruitment and selection of its elites is more universal, based on objective and formal rules. This elucidates the fact that Bourdieu (1996) has intentionally given greater emphasis to educational selection criteria than advantages that come from social capital in his examination of the elites he has studied.

Overcoming these problems is also of importance in considering the specific character of, and what was imported into, Brazilian state institutions at the time, which even though they were founded through acts of administrative reform based on the merit principle and the supposed relative autonomy of the bureaucratic sphere within the political universe, existed within the context of a personalization of social relationships. Therefore, we should consider them as imported institutions whose origins and the conditions that led to their appearance cannot be found in the importing country. Thus, this implies the effects of importing exogenous products and the consequent modifications of their usage in personal strategies to support the legitimacy of the elite positions that were previously framed by social capital (Badie, 1992; Badie \& Hermet, 1993; Dezalay \& Garth, 2002).

Based on this exposition, a central element of this analysis will be the subject of social trajectory (Bourdieu, 1997) to investigate the path of Luiz Simões Lopes from his aristocratic origins to his position as an elite national leader of the New State. Through this prism, instead of attributing a greater structural weight to strategies based on objective cultural capital, the analytical scheme will privilege the relationships between the accumulation of different forms of capital and adopt a multidimensional perspective in the sense that access to elites and their reproduction is supported by a specific combination of different types of capital. To elucidate the meaning of these relationships, it adopts, as mentioned above, the principle that social capital and personal relationships (Bourdieu, 1998) have greater structural weight within the historical context under examination, in the sense that other forms acquire different meanings, weights and uses due to it. It also includes the scheme of effects imported from the state models of the countries which have been central in local political struggles (Badie, 1992; Badie \& Hermet, 1993; Dezalay \& Garth, 2002), and the condition of the weak autonomy of social spaces that exists within peripheral societies, which are especially dependent on the political establishment (Coradini, 1997a, 1997b, 1998, 2003; Loureiro, 1997; Martins, 1987; Miceli, 2001a; Pécaut, 1990; Saint-Martin, 1988; Sigal, 2012).

The identification of conditioning factors should occur through the study of the respective social and professional trajectories of the agents involved. Grynszpan (1990) mentions the advantages of this analytical resource for this purpose:

The examination of individual trajectories enables us evaluate the strategies and actions of actors in various social situations and positions, their movements, their resources, the way in which they use or maximize them, their relationship networks, how they are structured and how they act, and whether they encourage them or abandon them (Grynszpan, 1990, pp. 74-75).

Journal of Public administration ｜ Rio de Janeiro 53(4):640-656, July - Aug. 2019 
Bourdieu (1997, p. 81) proposes that the concept of trajectory should be used to break with what he calls the "biographical illusion," or in other words, the common sense underlying the notions of biography and life stories which are presented as substantive, permanent and autonomous products of the life of an individual based on the matrix of social relationships to which this person belongs and the reality that he or she belongs to and is conditioned by. The trajectory thus breaks with this illusion which belongs to the fiction genre in considering life as a "series of positions successively occupied by the same agent (or the same group) in his or her own space which is subject to cycles and endless transformations" (Bourdieu, 1997, p. 81).

\section{METHODOLOGY AND SELECTION OF SOURCES}

The biographical method has been fertile in the reconstruction of trajectories associated with leading elites (Charle, 2006; Miceli, 2001b; Seidl, 2013). In light of the theoretical references adopted in this study, it takes on specific contours that differ from what is commonly associated with the application of "quantitative methods" in social sciences such as oral history and life stories. These specificities have been widely discussed (Bourdieu, 1997; Passeron, 1990; Peneff, 1994; Pudal, 1994) and may thus be summarized as: a) considering the objectivist as well as the subjectivist point of view in the reconstruction of the trajectory, with one being the objective character of social positions which have conditioned the existence of an agent, and the other the subjective nature of the positions taken and the representations made of oneself and to the world; b) the fact that the term "biographical" is considered here to be a method of historical research as well as the locus of data sources, signifying that it as an appropriate method for the reconstruction of social trajectories and paths as well as historical-biographical sources whose logic of production resides in the consecration of certain social profiles and resources (Grijó, 2008), the instruments of which leadership groups use in their reproduction strategies (Miceli, 2001b).

To reconstruct the Trajectory of Luiz Simões Lopes, historical sources and as well as sources of a completely apologetic nature have been used. Thus, Luiz's personal archives, which are collected in the Center for Research and Documentation of Contemporary Brazilian History (CPDOC) of the Getulio Vargas Foundation (FGV), have been consulted. From this material, entries from the Brazilian Historical-Biographical Dictionary (DHBB), personal letters and biographical reports that Luiz left to FGV have been used: on one hand we have statements from an oral history project of CPDOC/ FGV entitled The Trajectory and Performance of Brazilian Political Elites; on the other, we have the memorial book Luiz Simões Lopes: Fragments of Memory edited by the same institution. Even though these are distinct projects, one thing they have in common is that they are both the fruit of FGV institutional initiatives, whose effect, whether conscious or not, has been to eternalize certain notable facts concerning the individual who conceived of and created the institution.

\section{CONDITIONING FACTORS IN THE TRAJECTORY OF LUIZ SIMÕES LOPES (1903-1945)}

The ex-director of FGV's Brazilian School of Public and Business Administration (EBAPE) Bianor Scelza Cavalcanti, in prefacing Luiz Simões Lopes's memorial work, seeks to distinguish him as a "Vigorous, technical and authentic Brazilian with a public vision, a public man with entrepreneurial 
talent, a founder of institutions, an administrative pioneer, a trainer of educators, an educator of leaders, and founder, president and honorary president of FGV" (Cavalcanti, 2006, p. 15).

In addition to noting his character as a multi-faceted leader, Cavalcanti (2006) is emphatic in mentioning that:

Luiz Simões Lopes also always kept a perspective in terms of national issues [our italics] and kept an eye on what was happening in the developed world [...]. Without losing sight of his commitment to the nation's identity and interests, he was, as all these texts demonstrate, a citizen of the world who had strong convictions and a strategic sense of a mission (Cavalcanti, 2006, p. 16).

Along with noting his cosmopolitan traits and nationalist feeling and commitment to addressing "Brazilian problems," Cavalcanti (2006, p. 16) emphasizes that Simões Lopes's life was characterized by paradoxes, which did not interfere with his mission, because they gave him courage to detach himself from his social origins associated with the agrarian aristocracy of Rio Grande do Sul and follow a path that was "predestined," in the sense of fulfilling a calling to construct the Brazilian nation along rational lines:

Dr. Simões, as we called him with affection, respect, and at times, not without some fear, came from a southern imperial aristocratic family, even though his father soon embraced the Republican Revolution against the conservative interests common at the time among ranchers. The son of a politician with a degree in agronomy, he entered public life through his family's ties, but was always reticent in relation to the political class, which he did not hide from his closest collaborators, and was publicly against nepotism (Cavalcanti, 2006, p. 16).

This is an example of how his institutional investment led to his consecration. Possessing characteristics that at first appear contradictory, this human chameleon was eternalized precisely because of the traits that made up his disposition: being simultaneously cosmopolitan and nationalist, and being predestined as if a prophet and at the same time as rational as a priest. It was an unusual mixture of the rational and the transcendent that says a lot about the transformations which took place among the political elites at that time.

\subsection{Family origins}

Born on June 2, 1903 in the city of Pelotas, RS, Luiz Simões Lopes came from a traditional southern aristocratic ranching family which was well connected with local and national politics. Luiz's grandfather, João Simões Lopes Filho, a baron who later on was promoted to the title of Viscount de Graça, was also a rancher and President of the Province of Rio Grande do Sul in 1871. His father Ildefonso Simões Lopes was a member of the House of Representatives between 1906 and 1908 and between 1913 and 1919, Minister of Agriculture between 1919 and 1922 during the administration of Epitácio Pessoa, and resumed his career as a congressman from 1922 until 1930.

Based on the entry that appears in the DHBB (Moreira, 2001), it will be useful to examine the position of his father Ildefonso in order to shed light on the family strategies that influenced Luiz's 
trajectory. Born in Pelotas on November 19, 1866, Ildefonso initially preferred to be an engineer and obtained a diploma in engineering in 1890, working for a few years in constructing railroads in Minas Gerais, São Paulo and Rio de Janeiro. When he returned to Pelotas in 1895, he dedicated himself to the family business, managing his father's water company Hidráulica Pelotense until 1905. Ildefonso's reconversion to electoral politics only occurred later when he became a member of the Rio Grande Republican Party (PRR).

Ildefonso's ascension to local political power and later the national stage appears to be in keeping with the members of the political elite of Rio Grande do Sul who were born at the end of the $19^{\text {th }}$ century and began their careers with the PRR at the time when Borges de Medeiros was the President of the province. According to Grijó (1998), these men had social origins very similar to Ildefonso, because they were also from aristocratic families, although they mainly studied law. From Luiz's point of view (Simões Lopes, 1986), this privileged group assumed political power because it was natural that the most cultured group would do so. All maintained certain positivist ideals: once they became members of elite organizations within society, they were opposed to political liberalism, questioned individualism, defended the scientific nature of power, and valued public well-being above the interests of individuals (Pécaut, 1990).

In summary, the privileged background of Luiz's family and the increasing value placed on cultural capital as a resource for entering politics, ensured the conversion of the family's financial and social resources into the education of their children. Coradini (1997a) mentions that, by the weight given to personal relationships in strategies to rise within the elites, the entrance into, and the investment in education were very dependent on these clientelist relationships, which guaranteed admission to the most prestigious schools and redefined the significance of an educational degree as a guarantee of entrance into politics.

\subsection{Educational investment}

Even though he began studying at a small school in Pelotas, it was only with an abrupt move to Rio de Janeiro (Simões Lopes, 2006b) when his father was re-elected to congress in 1913 that Luiz began his educational trajectory at the Aldridge High School and the Liceu Francês. They were excellent institutions. As Luiz himself stated, "besides offering good courses, they taught us good morals and the Catholic religion even though we were Protestants, sports, personal dignity, courage and loyalty" (Simões Lopes, 2006a, p. 47).

Concluding his initial schooling, Simões Lopes (2006a, p. 48) affirms that he felt "attracted to an agronomic career, maybe because of my unforgettable memories on my grandfather's property." He didn't regret this later, judging that his choice was very useful, even though life took him "on a different path" (Simões Lopes, 2006a, p. 48). Dedicating himself to study, he moved to the small city of Piracicaba, outside of the city of São Paulo, in 1920 to enroll in Agronomic Engineering at the Luiz de Queiroz Agricultural School.

Simões Lopes (2006a, p. 51) had very fond memories of his fellow students, professors and the community in Piracicaba in general, because he "knew everyone from the mayor to the shoe shiner and had great relationships with families in Piracicaba including the sizeable colony from Rio Grande do Sul." From his days there in local associations, he remembered that they were the principal revitalizing 
agents of the Luiz de Queiroz Agricultural Center, an entity that included professors and students of which he became President. In his memoirs, he mentions: "By virtue of the position that I assumed as a student leader, I was always called upon to intervene in conflicts between the students and the population" (Simões Lopes, 2006a, p. 51).

But these times of peace ended when he was involved in an incident with a soldier of the Military Police which resulted in his being wounded and being kicked out of the Agricultural School. After his recovery, he was obliged to transfer to Belo Horizonte, and in 1924 he finished his last year in agronomic engineering at the Minas Gerais School of Agronomy and Veterinary Medicine and received his degree. It was due not only to his professional degree, but also, and mainly due to a set of personal relationships based on his father's ties to the federal political elite that he managed to enter the public civil service through a recommendation from the Minister of Agriculture Miguel Calmon to work in his ministry.

\subsection{Entering public service}

Even though he had pulled strings to enter the Ministry of Agriculture, Luiz states that he was profoundly shocked to observe how most of the public employees themselves entered, "without passing any exam, or proving any technical abilities or moral suitability" (Simões Lopes, 2006a, p. 54). Since there still were no career mechanisms based on formal rules for entering and progressing in the public civil service, when he entered due to a political recommendation, Luiz was able to choose among all the various positions that were still available. Based on "common sense" (Simões Lopes, 2006a, p. 54), he chose the lowest position among those on offer, in an experimental station that worked with forage plants. Sometime later, Minister Calmon offered him a position in his ministerial cabinet, which he accepted because he was not happy with the director of his division. There he met "excellent employees like Paulo Vidal, who later worked with me in DASP, Arno Konder, who later became ambassador, and various others. I learned a lot, and established great relationships with politicians, authorities and society in Rio de Janeiro" (Simões Lopes, 2006a, p. 55).

If until 1929 Luiz was an employee in the cabinet of the Minister of Agriculture handling specific technical environmental issues, that year, beginning with the campaign begun by the Liberal Alliance (AL), he dedicated himself more and more to involvement in the nation's "political problem" (Simões Lopes, 2003, p. 2). His political relationship with the AL began due to the fact that his father was the Vice President of the group. Since he considered his father to be its "true President," he became his sort of personal secretary. The alliance's campaign to elect Getúlio Vargas encountered difficulties in the states other than Rio Grande do Sul, Minas Gerais and Paraíba, because these states supported the candidacy of Júlio Prestes from São Paulo. The result after Prestes's victory was, as you know, the Revolution of 1930 which led to Vargas's alliance installing the Provisional Government.

Luiz's proximity to Vargas began not just because of his active participation in the Revolution of 1930, but also because of the personal relationships that already existed between the Simões Lopes and Vargas families, who were friends since the 1920s, when Getúlio and Ildefonso represented Rio Grande do Sul in the House of Representatives. The family social capital accumulated and inherited by Luiz through these relationships between these families played a strong role in Vargas's decision to appoint him to a privileged position in his presidential cabinet. 
In parallel to this, the events that led Vargas to power represented the moment in which Luiz began to broaden and diversify the spectrum of his interests from beyond mainly technical issues to the daily functioning of the government, taking new positions in relation to national political challenges and problems mainly related to the need to reform the scientific basis for public service in Brazil.

\subsection{Access to Vargas's political elite}

Luiz's participation in the Revolution of 1930 was episodic and restricted to Rio Grande do Sul. He was not successful in organizing a local force to join together with the revolutionary troops. Since he was still a public employee in Rio de Janeiro, Luiz was obliged to return to the capital. Considering that Luiz and Vargas already knew each other due to their family relationships, as soon as he returned to Rio, Vargas, who already was the Head of the Provisional Government, called him personally to offer him the position of his Chief of Staff.

Initially when he assumed the leadership of the Provisional Government, Vargas decided to bring with him two associates who had worked with him in the government of Rio Grande do Sul. They, however, did not know Rio de Janeiro well and did not have the good relationships with politicians, authorities and society in Rio de Janeiro that Luiz possessed through his time in the cabinet of the Minister of Agriculture and as the personal secretary of his father in the AL. Since Vargas already had a relationship with Luiz, and knowing that he had worked in a cabinet, he believed that Luiz could put order in the disarray of his cabinet and organize his presidential agenda. Thus, Luiz remained in this position until 1936, when Vargas himself again invited him to be President of the Civil Employee Readjustment Commission, one of his great initiatives in administrative reform.

His immersion in Vargas's cabinet, together with the impressions that Luiz had begun to form in the 1920s, which starting in 1930 became more robust, namely his penchant for the rational organization of the government's functioning and his enthusiasm for the Revolution of 1930, were enough to win the confidence of the new president, making him the main person handling the administrative reform that this government intended to see through.

The purpose of rational organization, as can be seen in the positions taken by Luiz, was that it was an axis that united the new government's "competence to manage" with "elevated moral integrity" and "reason," ideals that had already been a part of the Rio Grande do Sul school of positivism, which he had acquired through his precocious contact with the political elite of his home state, and which now had become consolidated into a national elite: "it seemed to be the instrument capable of transforming Brazil into the country of our dreams, prosperous, free, happy, managed by a highly competent, honest and well-intentioned government, inspired by morality and reason, as the positivists said" (Simões Lopes, 2006d, p. 77).

\subsection{Leadership before the Creation of DASP}

Having occupied his official post in Vargas's cabinet, Luiz, starting in 1935, began to participate actively in the reform of the public civil service, promoted by the Vargas administration with the creation of the Bipartisan Commission on Economic-Financial Reform. However, this commission's final report was not accepted by the legislature. A new attempt was made in 1936, when Vargas created 
the Readjustment Commission with Luiz as its President. A new bill was sent to the legislature, which suggested some amendments, but due to the strength of the government in the House, they were rejected. Thus, the "law was passed free from the assaults made to alter it to serve their own personal interests, and thus it became Law 284 of 1936" (Simões Lopes, 2006c, p. 91). In regard to this law, Simões Lopes (2006c) took the following position:

Besides organizing the personnel system, it brought with it a series of principles that are indispensable to modern, non-random, administration, ruled by general, honest and rigid norms that from that point forward guided the Brazilian civil service. It was a monolithic system, performed with absolute honesty that dispensed equal treatment for all (Simões Lopes, 2006c, p. 91).

Vargas thus named Luiz to preside over the Federal Board of Public Civil Service (CFSPC), a government body created by Law no 284 to apply new norms until its extinction at the end of 1937, when the New State was installed, which closed Congress and created a new Federal Constitution, making efficiency in public service a constitutional principle "as a duty of the state to the country and its citizens as a people" (Simões Lopes, 2006c, p. 92). In the same way, the new Constitution of 1937 created a government body that substituted the CFSPC, which was now placed directly under the Office of the President of the Republic. Luiz was named the President of this new body DASP, and there he remained until the regime's end in 1945, which possessed greater regulatory and invasive power than its predecessor.

In his decision making during this time as he assumed the highest level of the public bureaucracy through DASP, Luiz Simões Lopes attributed greater and greater importance to public service. In a letter found in his personal archive within the CPDOC unaddressed and undated, we can observe the maturing of the positions that he began taking with his engagement in the Revolution of 1930: placing himself at the service of national causes and the country's progress via the modernization of the public sector:

My love for public service and national causes had no limits. Any sacrifice required of me was met unconditionally. I thought myself possessed by the spirit of my mission, and my youth gave me the enthusiasm and force to face any difficulty. It was an unequal fight without quarter. I didn't rest and it wasn't rare for me to be threatened, attacked, or vilified for defending what I deemed to be in the highest interests of the state. I dreamed of creating a great public service that would be capable and appropriate and would be respected as the most powerful instrument for the progress of Brazil (Simões Lopes, s.d).

The broad modernization that Luiz conducted when he presided over the DASP was mainly based on the organization of formal mechanisms for career initiation and advancement and the principles of the rational organization of work. His roots in terms of doctrine, according to Siegel (1964), were mainly based on American scientific administration, making this notoriously cosmopolitan individual attentive in observing the most modern administrative practices in the world. 
There was no lack of references to American literature and practices related to Gulick's concepts of planning, organizing, staffing, directing, coordinating, reporting and budgeting (Posdcorb), which was the functional model of the American Civil Service Commission, and the concepts of Willoughby about the roles of departments in overall administration with support from the Executive Branch, and the distinction between means (administration) and ends (policy) in governmental actions. However, Luiz's DASP did not abdicate its role in adapting all of this to the Brazilian "experience" (Wahrlich, 2001, p. 1828). In other words, it operated in the adaptation of liberal democratic ideas and consolidated them within the context of an authoritarian government, giving the department broad power to attain the regime's political objectives and oppose the irrationality of the old political oligarchies, always acting in the name of science and the organization of the nation on a rational basis (Pécaut, 1990).

More specifically, the actions of Luiz in DASP generated a series of modernizing devices. Among these was the management of materials, such as a unified system which came into force beginning in 1939 for public works and buildings, controlling construction and renovations, and establishing norms for budgets, projects and contracts. There were also advances in the organization of work, in which DASP centralized all the research activities and projects using work methods created by a subdivision devoted exclusively to this subject.

In order to centralize activities as much as possible, the recruitment of public servants was also institutionalized based on meritocratic principles through entrance exams and the responsibility to hold them. Parallel to these exams, a new technical career in administration was created to be filled in by the people who passed the exams. In addition to recruitment, Luiz was concerned with career advancement. To address this, he institutionalized in DASP the idea of professional qualifications and improvement. As Simões Lopes informs us (2003), two fronts were created: the training courses themselves and improvement courses based on Decree-Law no 2,804 of 1940; and sending public servants abroad for training in technical courses and internships based on Decree-Law n $\mathbf{0} 776$ of 1938, with the main receiving institution being the School of Public Affairs of American University. As Wahrlich points out (1983), DASP's courses and its sending of employees abroad was an important event in the training of professional Brazilian administrators, and was a pioneering program in this country.

Another pioneering action of Luiz's at the helm of DASP should also be mentioned. This was the creation of the Public Service Magazine (RSP), which contributed to the construction of a new technical and scientific mentality in public service, which disseminated ideas on scientific administration and organization throughout Brazil with DASP making positive allusions to the regime and promoting the benefits of the modernization which was taking place.

It's possible to note that during this regime Luiz attributed to himself the status of an elite leader, because he saw himself as a member of the efficient and modern group which was opposed to the "old form of administration" which survived on a local level, which was the fruit of the backward political oligarchies that existed within the states. According to Simões Lopes (2003, p. 41), "the states and municipalities did not understand the need for this and also did not like it, because they preferred to retain total freedom as they had always had in naming whomever they wanted with no exams or criteria for their admittance. They admitted their relatives." There is a lot of evidence that 
he saw himself as a capable leader with a mission to defend the broad interest of constructing the nation (Pécaut, 1990), which is expressed by the positions that he took, such as:

Motivated by an immense love of the government cause, we were the messengers of a new idea. Wherever we went we preached a message of greater and greater confidence in our work methods and in the government's guidance. We were all knights with a cause and we never accepted our victories as final, but always believed that we should make more and more contributions to the public administration of our country. Thus, we spent many years in battle, gratified by the intimate conviction that we were doing something that was very important to the life of the country (Simões Lopes, 1986, p. 51).

In the same manner, great importance was given to the role of the state in "poor nations." Simões Lopes's perception (1986) was directed towards the need for a strong state that was developing and modernizing like Brazil, because he believed that in wealthy countries private initiative was capable of propelling the country forward to promote and develop it through work, greater productivity, higher salaries and a better standard of living. In poor countries, nomenclature that he himself used, the state has an immense task to perform:

In underdeveloped and poorer countries, the government should be made up of the nation's intellectual elite, the most prepared men, the most intelligent, patriotic, and dedicated men who have a sense of commitment to public service, who feel responsible for the people, who want to make their country a model nation (Simões Lopes, 1986, p. 52).

Beginning in the 1940s, Luiz began to argue that there was an urgent need to create a specific institution to "take care of the country's problems." But, since he was aware that it would not be possible to take care of everyone, the "social sciences" were chosen as the main solution for these ills, with an emphasis on administration and economics. Most of the problems faced by DASP were concentrated in these two fields. Thus, it was that in 1944 he participated directly in the creation of FGV: "In this manner, I created in Brazil the most modern thing that existed in the United States" (Simões Lopes, 2003 , p. 54). At the end of the regime, with the fall of Vargas, Luiz decided to leave the presidency of DASP and dedicated himself to leading FGV as its first President.

\section{CONCLUSION}

In light of the evidence here presented, we have observed that the social origins of Luiz Simões Lopes were associated with the ranching aristocracy of Rio Grande do Sul. However, his memoirs demonstrate that he tried to deny them, whether it was affirming that he never had "a vocation for politics" or referring to the family ranch just as a "refuge." From an early age, he displayed a vocation for being an "administrator." But, despite his references in terms of administrative science, neutrality, impartiality and being apolitical, Luiz was also one of the great political and cultural intermediaries between 1930 and 1945. Even though his trajectory was marked by positions which were based on the legitimacy of scientific-rational knowledge as opposed to the traditional "old politics" which 
he had been linked to since birth, the bases of his decision making remained founded on personal relationships, made possible by his inherited social capital and acquired during his trajectory. Even though he tried to deny this, these "traditional" dispositions appear to be in keeping with the most modern innovations of the West that he brought to Brazil.

This becomes clear based on the evidence that has been presented. When the first reformers of public administration began to unite around the Readjustment Commission and the CFSPC, Luiz was the man of confidence who was the intermediary between the policy choices of the reformers and Vargas, and it was also he who played an intermediary role in the choices made by DASP, justifying his choices through an amalgam of technical knowledge, confidence and the high morals of the men selected. To do this, it wasn't enough to be a specialized expert, an exemplary administrator in the technical sense. It was necessary to also be a man of high moral standing committed to a "mission" to "construct the nation" (Pécaut, 1990).

As mentioned above, his theoretical resources helped him think about these issues. In a peripheral society, where impersonal mechanisms of domination are not sufficiently structured, personal symbolic capital is relied on (Coradini, 1997a), always associated with personal relationships that make it possible. In these terms, what can be observed in Luiz's trajectory, is not just that his successive elite leadership positions he gained through his personal relationships, but also in parallel, he sought to legitimize his notoriety through the definition of his role as a "modernizing hero" who was respectively on a "mission" that he envisaged as "constructing the nation," giving himself exclusively a "broader role" in society. In this manner, in his memoirs Luiz defines himself as part of the elite through an amalgam of impersonal and personal characteristics.

This explanation can well be treated as part of the transformation of the universe of political grammar (Nunes, 2003), which is focused on the level of state institutions. From this point of view, one can observe that during the 15 years of Vargas's first government, three new grammars (corporatism, bureaucratic insularity and procedural universality) were mobilized in a universe where the clientelist grammar had previously prevailed. This new composition influenced the access of remaining state oligarchies of the Old Republic in the New Republic. But rather than focusing on the sphere of institutional transformation, this study is concerned with the transformation of national political elites based on the analysis of a specific trajectory.

The case of Luiz is, as we have seen, particularly illustrative of the contradictory tone that characterized this time: the fact that the post-1930 modernization of the state was the work of an aristocratic agrarian elite in a peripheral state of the federation (in this case Rio Grande do Sul) which opposed the dominance of São Paulo (Garcia, 1993b). It may be questioned why a man whose political power was based precisely on personal characteristics made so much effort to seek legitimacy for a political elite, which in theory, universalized access to all of the most prestigious positions and minimized the previous power bases which offered them restrictive access.

In this case, dual schemes cannot be used to solve this problem (Garcia, 1993b). By placing the traditional universe on one side and the modernization of the state on the other, they avoided showing that the strategies of these new national political elites, in the case of Luiz, were playing with strategic diversification and putting into action various forms of capital, ably reserving the most attractive posts while expanding competition as a consequence of the arrival of "universal principles" 
in recruitment and selection. Perhaps the broadest conclusion that we can extrapolate from this is that certain traditional families from politically peripheral states began to diversify their strategies to affirm the political power linked to the trajectories of their descendants and transfer the resources associated with economic and social capital to investments in cultural capital.

Instead of dualism, think of the amalgam that resulted, a contradiction unresolved by history, in an aristocratic agrarian heir from Rio Grande do Sul managing to become a leader on a national level whose role was that of a "modernizing hero," the bearer of a "mission" of national construction, who knew how to ably deal with his personal bases that always conditioned his ascension strategies to the national elite and his role as a mediator through the universal principles that he imported, which included his role in the importing of American scientific administration to the Brazilian state. This amalgam resulted from the fact that the access to this role of mediator in the import of these universal principles was not universal, but rather closed to a cosmopolitan elite (Dezalay \& Garth, 2002) which felt it was participating in a heroic mission, or in other words, the bearers of a trait so distinctively personal that it could only be acquired with support based on personal relationships.

From this one can finally conclude that it was the redefinitions of science and technical knowledge that established the basis for his policy positions which were quite in tune with the broader interests of the New State's regime of arguing for an "objective and administrative policy" (Pécaut, 1990, p. 56), redefinitions which were only possible due to the previous accumulation of personal symbolic capital. In other words, in the name of universal and general principles, only the singular bearers of a transcendental sense of a heroic mission, linked to the bearer's charisma, Luiz in this case, could lead a chaotic and disorganized nation, an amorphous mass of atoms seeking a definite direction, to this self-realization. 


\section{REFERENCES}

Badie, B. (1992). L'État importé : l'occidentalisation de l'ordre politique. Paris, France: Fayard.

Badie, B., \& Hermet, G. (1993). Política comparada. México, DF: Fondo de Cultura Económica.

Bordignon, R. R. (2013). Origens sociais, ascensão "profissional" e concepções de ciências sociais: Florestan Fernandes e Fernando Henrique Cardoso. TOMO, 16(22), 181-220.

Bourdieu, P. (1982). Leçon sur la leçon. Paris, France: Minuit.

Bourdieu, P. (1996). The state nobility: elite schools in the field of power. Palo Alto, CA: Stanford University Press.

Bourdieu, P. (1997). Razões práticas: sobre a teoria da ação. Campinas, SP: Papirus.

Bourdieu, P. (1998). O capital social: notas provisórias. In M. A. Nogueira, \& A. Catani (Orgs.), Escritos de educação (pp. 65-69). Petrópolis, RJ: Vozes.

Bourdieu, P. (2004). Espaço social e poder simbólico. In Autor, Coisas ditas (pp. 149-168). São Paulo, SP: Brasiliense.

Bourdieu, P. (2008). Modos de dominação. In Autor, A produção da crença: contribuição para uma economia dos bens simbólicos (3a ed., pp. 191-219). Porto Alegre, RS: Zouk.

Bourdieu, P. (2011). O senso prático (2a ed.). Petrópolis, RJ: Vozes.

Cavalcanti, B. S. (2006). Prefácio. In S. B. Silva (Org.), Luiz Simões Lopes: fragmentos de memória (pp. 1521). Rio de Janeiro, RJ: Ed. FGV.

Charle, C. (2006). A prosopografia ou biografia coletiva: balanço e perspectivas. In F. M. Heinz (Org.), Por outra história das elites (pp. 41-53). Rio de Janeiro, RJ: Ed. FGV.

Codato, A. N., \& Franz, P. (2018). Ministros-técnicos e ministros-políticos nos governos do PSDB e do PT. Revista de Administração Pública, 52(5), 776-796.

Constituição dos Estados Unidos do Brasil, de 10 de novembro de 1937. (1937). Rio de Janeiro, DF.

Coradini, O. L. (1997a). Grandes famílias e elite "profissional" na medicina no Brasil. História, Ciências, Saúde: Manguinhos, 3(3), 425-466.
Coradini, O. L. (1997b). Origens sociais e princípios de hierarquização escolar: a formação de "intelectuais à brasileira”. Cadernos de Ciência Política, 2(6), 1-55.

Coradini, O. L. (1998). Panteões, iconoclastas e as ciências sociais. In L. O. Félix, \& C. P. Elmir (Orgs.), Mitos e heróis: construção de imaginários (pp. 209235). Porto Alegre, RS: Ed. UFRGS.

Coradini, O. L. (2003). As missões da "cultura" e da "política": confrontos e reconversões de elites culturais e políticas no Rio Grande do Sul (19201960). Estudos Históricos, 2(32), 125-144.

Coradini, O. L. (2008). As elites como objeto de estudos. In Autor (Org.), Estudos sobre grupos dirigentes no Rio Grande do Sul: algumas contribuições recentes (pp. 7-18). Porto Alegre, RS: Ed. UFRGS.

Decreto-Lei n. 776, de 7 de outubro de 1938. (1938). Dispõe sobre especialização e aperfeiçoamento de funcionários públicos civis federais no estrangeiro e dá outras providências. Rio de Janeiro, DF.

Decreto-Lei n. 2.804, de 21 de novembro de 1940. (1940). Dispõe sobre a organização de Cursos de Administração e dá outras providências. Rio de Janeiro, DF.

Dezalay, Y., \& Garth, B. (2002). The internationalization of palace wars: lawyers, economists and the contest to transform Latin America States. Chicago, IL: University of Chicago Press.

Diniz, E. (1999). Engenharia institucional e políticas públicas: dos conselhos técnicos às câmaras setoriais. In D. C. Pandolfi (Org.), Repensando o Estado Novo (pp. 21-38). Rio de Janeiro, RJ: Ed. FGV.

Garcia, A., Jr. (1993a). Les intellectuels et la conscience nationale au Brésil. Actes de la Recherche en Sciences Sociales, 18(98), 20-33.

Garcia, A., Jr. (1993b). Reconversion des élites agraires: du pouvoir local au pouvoir national. Études Rurales, 32(131-132), 89-106.

Graham, L. S. (1968). Civil service reform in Brazil: principles versus practice. Austin, TX: University of Texas Press.

Grijó, L. A. (1998). Origens sociais, estratégias de ascensão e recursos dos componentes da chamada "geração de 1907" (Master Thesis). Universidade Federal do Rio Grande do Sul, Porto Alegre, RS. 
Grijó, L. A. (2008). Biografia, para quê? In O. L. Coradini (Org.), Estudos de grupos dirigentes no Rio Grande do Sul: contribuições recentes (pp. 85-102). Porto Alegre, RS: Ed. UFRGS.

Grill, I. G. (2015). As múltiplas notabilidades de Afonso Arinos: biografias, memórias e a condição de elite no Brasil do século XX. Revista de Sociologia e Política, 23(54), 21-42.

Grynszpan, M. (1990). Os idiomas da patronagem: um estudo da trajetória de Tenório Cavalcanti. Revista Brasileira de Ciências Sociais, 5(14), 73-90.

Lei n. 284, de 28 de outubro de 1936. (1936). Reajusta os quadros e os vencimentos do funccionalismo publico civil da União e estabelece diversas providencias. Rio de Janeiro, DF.

Loureiro, M. R. (1997). Os economistas no governo: gestão econômica e democracia. Rio de Janeiro, RJ: Ed. FGV.

Martins, L. (1987). A gênese de uma intelligentsia: os intelectuais e a política no Brasil (1920 a 1940). Revista Brasileira de Ciências Sociais, 2(4), 65-87.

Miceli, S. (1981). Carne e osso da elite política brasileira. In B. Fausto (Org.), História geral da civilização brasileira: o Brasil Republicano sociedade e política (1930-1964) (pp. 574-578). São Paulo, SP: Difel.

Miceli, S. (2001a). Intelectuais e classe dirigente no Brasil (1920-1945). In Autor, Intelectuais à brasileira (pp. 69-291). São Paulo, SP: Companhia das Letras.

Miceli, S. (2001b). Biografia e cooptação (o estado atual das fontes para a história social e política das elites no Brasil). In Autor, Intelectuais à brasileira (pp. 345-356). São Paulo, SP: Companhia das Letras.

Moreira, R. L. (2001). Ildefonso Simões Lopes. In A. A. Abreu (Coord.), Dicionário histórico-biográfico brasileiro: pós-1930 (2a ed., pp. 3270-3272). Rio de Janeiro, RJ: Ed. FGV.

Nunes, E. O. (2003). A gramática política do Brasil: clientelismo e insulamento burocrático (3a ed.). Rio de Janeiro, RJ: Zahar.

Passeron, J.-C. (1990). Biographies, flux, itinéraires, trajectoires. Revue Française de Sociologie, 31(1), 3-22.
Pécaut, D. (1990). Os intelectuais e a política no Brasil: entre o povo e a nação. São Paulo, SP: Ática.

Peneff, J. (1994). Les grandes tendances de l'usage des biographies dans la sociologie française. Politix, 7(27), 25-31.

Petrarca, F. R. (2017). De coronéis a bacharéis: reestruturação das elites e medicina em Sergipe (1840-1900). Revista Brasileira de História, 37(74), $89-112$.

Pudal, B. (1994). Du biographique entre "science" et "fiction". Quelques remarques programmatiques. Politix, 7(27), 5-24.

Saint-Martin, M. (1988). À propos d'une rencontre entre chercheurs. Sciences sociales et politique au Brésil. Actes de la Recherche en Sciences Sociales, 13(71-72), 129-134.

Sapiro, G. (2012). Modelos de intervenção política dos intelectuais: o caso francês. Revista Pós Ciências Sociais, 9(17), 19-50.

Seidl, E. (2008). Elites militares, trajetórias e redefinições político-institucionais (1850-1930). Revista de Sociologia e Política, 16(30), 199-220.

Seidl, E. (2010). A formação de um exército à brasileira: lutas corporativas e adaptação institucional. História, 29(2), 71-94.

Seidl, E. (2013). Estudar os poderosos: a sociologia do poder e das elites. In E. Seidl, \& I. G. Grill (Orgs.), As ciências sociais e os espaços da política no Brasil (pp. 179-226). Rio de Janeiro, RJ: Ed. FGV.

Seidl, E., \& Grill, I. G. (2013). A política como objeto de estudo nas ciências sociais. In Autores (Orgs.), As ciências sociais e os espaços da política no Brasil (pp. 7-20). Rio de Janeiro, RJ: Ed. FGV.

Siegel, G. B. (1964). The vicissitudes of governmental reform in Brazil: a study of the Dasp (Ph.D. Thesis). University of Pittsburgh, Pittsburgh, PA.

Sigal, S. (2012). Intelectuais, cultura e política na Argentina. Revista Pós Ciências Sociais, 9(17), 51-66.

Silva, S. B. (Org.). (2006). Luiz Simões Lopes: fragmentos de memória. Rio de Janeiro, RJ: Ed. FGV.

Simões Lopes, L. (1986). Luiz Simões Lopes (Vol. 1, 1979, 1981). Rio de Janeiro, RJ: Centro de Pesquisa e Documentação de História Contemporânea do Brasil. 
RAP | The history of Luiz Simões Lopes: a leader between administration and politics

Simões Lopes, L. (2003). Luiz Simões Lopes (Vol. 2, 1990). Rio de Janeiro, RJ: Centro de Pesquisa e Documentação de História Contemporânea do Brasil.

Simões Lopes, L. (2006a). Amor à natureza. In S. B. Silva (Org.), Luiz Simões Lopes: fragmentos de memória (pp. 45-59). Rio de Janeiro, RJ: Ed. FGV.

Simões Lopes, L. (2006b). O privilégio de ser gaúcho. In S. B. Silva (Org.), Luiz Simões Lopes: fragmentos de memória (pp. 23-43). Rio de Janeiro, RJ: Ed. FGV.

Simões Lopes, L. (2006c). Paixão pela administração. In S. B. Silva (Org.), Luiz Simões Lopes: fragmentos de memória (pp. 85-117). Rio de Janeiro, RJ: Ed. FGV.
Simões Lopes, L. (2006d). Política: tragédia e revolução. In S. B. Silva (Org.), Luiz Simões Lopes: fragmentos de memória (pp. 61-83). Rio de Janeiro, RJ: Ed. FGV.

Simões Lopes, L. (n.d.). Correspondência (sem título). Rio de Janeiro, RJ: Centro de Pesquisa e Documentação de História Contemporânea do Brasil.

Wahrlich, B. M. S. (1983). Reforma administrativa na era de Vargas. Rio de Janeiro, RJ: Ed. FGV.

Wahrlich, B. M. S. (2001). Departamento Administrativo do Serviço Público. In A. A. Abreu (Coord.), Dicionário histórico-biográfico brasileiro: pós-1930 (2a ed., pp. 1827-1830). Rio de Janeiro, RJ: Ed. FGV.

\section{Daniel Ouriques Caminha}

https://orcid.org/0000-0003-2933-9852

$\mathrm{PhD}$ student in Administration at the State University of Santa Catarina (Esag/Udesc); Master's degree in Administration from the School of Administration at the Federal University of Rio Grande do Sul (EA/UFRGS). E-mail: dan.caminha@gmail.com 